\title{
19. HELIUM AND SULFUR ISOTOPES OF SULFIDE MINERALS FROM MIDDLE VALLEY, NORTHERN JUAN DE FUCA RIDGE ${ }^{1}$
}

\author{
F.M. Stuart, ${ }^{2}$ R. Duckworth, ${ }^{3}$ G. Turner, ${ }^{2}$ and P.F. Schofield ${ }^{2}$
}

\begin{abstract}
The noble gas composition of fluids trapped in sulfides at Ocean Drilling Program Leg 139, Site 856, were measured. Helium in these fluids is significantly enriched relative to deep oceanic waters but is considerably lower than the helium contents of mid-ocean ridge (MOR) vent waters and fluid inclusions in sulfide minerals from $21^{\circ} \mathrm{N}$ on the East Pacific Rise. Sulfide ${ }^{3} \mathrm{He} /{ }^{4} \mathrm{He}$ ratios, corrected for air using He/Ne ratios, are between 5.8 and 7.1 times the air value $\left(\mathrm{R}_{\mathrm{a}}\right)$. These ratios are lower than those of typical MOR vent fluids $\left(\sim 8 \mathrm{R}_{\mathrm{a}}\right)$, and are closer to those of vent waters from the sediment-covered Guaymas Basin because of the dilution of a normal MOR He component by radiogenic He. The radiogenic He may be derived either from sedimentary pore fluids or from aging of the magmatic system beneath the northern Juan de Fuca Ridge. Low He abundances precluded sufficiently accurate ${ }^{3} \mathrm{He} /{ }^{4} \mathrm{He}$ measurements to identify subtle depth variations that could be used to understand temporal evolution of the hydrothermal system. A broad negative $\delta^{34} \mathrm{~S}-{ }^{3} \mathrm{He}{ }^{4} \mathrm{He}$ trend is identified that is consistent with a sedimentary origin for the radiogenic $\mathrm{He}$ at Middle Valley. ${ }^{40} \mathrm{Ar}{ }^{36} \mathrm{Ar}$ and $\mathrm{Xe}$ isotope ratios imply an atmospheric origin for the heavy noble gases that probably originate in minor hydrated minerals, which precludes the determination of absolute abundances of $\mathrm{He}$ in the fluid inclusions.
\end{abstract}

\section{INTRODUCTION}

Isotopic measurements of helium in oceanic basalts (Lupton and Craig, 1975; Kurz et al., 1982; Allègre et al., 1983) have shown that the mantle beneath the global mid-ocean ridge (MOR) system is characterized by a uniform composition. ${ }^{3} \mathrm{He} /{ }^{4} \mathrm{He}$ ratios display a narrow range, between 8 and 10 times the atmospheric value $\left(R_{a}\right)$, and are three orders of magnitude greater than that of radiogenic helium (e.g., Morrison and Pine, 1955) that characterizes the continental crust. The distinctive composition of upper mantle $\mathrm{He}$ is widely considered to be what remains of the primordial gases after the degassing of a significant portion of the Earth's interior (Allègre et al., 1983). The low ${ }^{3} \mathrm{He}$ production rate in the continental crust and the low abundance of $\mathrm{He}$ in the atmosphere allows the detection of small additions of mantlederived ${ }^{3} \mathrm{He}$ to surface fluids (see Lupton, 1983a, for review).

Extensive surveys have revealed excesses of ${ }^{3} \mathrm{He}$ in the water column above mid-ocean ridges (e.g., Craig et al., 1975; Jenkins et al., 1978; Lupton et al., 1980), at sites of extension of the oceanic crust (Lupton, 1979), and at sites of intraplate volcanism (Horibe et al., 1983; Kodera et al., 1988). The recognition that "primordial" He is scavenged from recently emplaced oceanic crust and released in plumes of hot (metal-rich) waters (Craig et al., 1975) supports models of hydrothermal circulation of seawater previously proposed to account for the low conductive heat flow at ridge crests, the $\delta^{18} \mathrm{O}$ depletions in ocean floor and ophiolitic basalts, and the presence of metalliferous sediments at Pacific ridge crests. Subsequent detailed chemical studies showed that the hydrothermal end-member solutions $\left(350^{\circ} \mathrm{C}\right)$ can be enriched in ${ }^{3} \mathrm{He}$ by in excess of 20,000 times that of ambient seawater (Butterfield et al., 1990). ${ }^{14} \mathrm{C}$-based estimates of the residence time of ${ }^{3} \mathrm{He}$ in the oceans allowed Craig et al. (1975) to calculate the flux of mantle-derived $\mathrm{He}$ from the solid Earth, which has subsequently been used to estimate the global fluxes of many other elements (see Le Cloarec and Marty, 1991, for review). Early studies of ridge-crest hydrothermal systems revealed rather constant $\mathrm{He} /$ heat ratios from which Jenkins et al. (1978) calculated the global hydrothermal heat flux from the oceans to be $2 \times 10^{-20} \mathrm{~J} / \mathrm{yr}$, close to

${ }^{1}$ Mottl, M.J., Davis, E.E., Fisher, A.T., and Slack, J.F. (Eds.), 1994. Proc. ODP, Sci. Results, 139: College Station, TX (Ocean Drilling Program).

${ }_{2}^{2}$ Dept. Geology, University of Manchester, Manchester M13 9PL, United Kingdom.

${ }^{3}$ Dept. Geology, University of Wales, Cardiff CF1 3YE, United Kingdom. independent estimates made from geophysical considerations. However, more recent work suggests that $\mathrm{He}$ concentrations and ${ }^{3} \mathrm{He} / \mathrm{heat}$ ratios in hydrothermal systems vary on short time scales (Lupton et al., 1989; Baker and Lupton, 1990). This is most likely to occur in response to fundamental tectonomagmatic processes occurring at midocean ridges (Baker and Lupton, 1990), and the apparent global uniformity of ${ }^{3} \mathrm{He} /$ heat ratios probably represents hydrothermal systems at equilibrium.

He isotope information, until now available only from the study of vent fluids, was recently acquired by in vacuo crushing of sulfide minerals from chimneys at $21^{\circ} \mathrm{N}$ on the East Pacific Rise (EPR) (Turner and Stuart, 1992). The ${ }^{3} \mathrm{He} /{ }^{4} \mathrm{He}$ ratios in these samples is identical to that of the vent waters, whereas $\mathrm{Ar}, \mathrm{Kr}$, and $\mathrm{Xe}$ abundances and isotopes imply that the heavy noble gases are derived from an atmospheric source. ${ }^{3} \mathrm{He} /{ }^{\beta 6} \mathrm{Ar}$ ratios provide information on the degree of water-rock interaction and reveal a perceptible enrichment of $\mathrm{He}$ in the trapped fluids over that measured in contemporary vent fluids. This may reflect the evolution of ocean-floor hydrothermal systems similar to the one detected in the "megaplume" over the Juan de Fuca Ridge in 1986 (Baker et al., 1987). However, we cannot rule out the possibility that the trapping of vent fluids fractionates the noble gases.

Here we present the results of a study of the He and Ne trapped in fluid inclusions within pyrite from the massive sulfide discovered at Site 856 on the Juan de Fuca Ridge during Ocean Drilling Program (ODP) Leg 139. ${ }^{3} \mathrm{He} /{ }^{4} \mathrm{He}$ ratios are used to constrain the origin of the hydrothermal fluid by allowing a direct comparison with ${ }^{3} \mathrm{He} /{ }^{4} \mathrm{He}$ ratios determined for vent fluids from other ridge-crest hydrothermal systems. Samples from different depths have also been analyzed in an attempt to place constraints on the He isotope evolution of an oceanfloor hydrothermal system.

\section{SAMPLES AND EXPERIMENTAL PROCEDURE}

We determined the noble gas composition of fluids trapped in pyrite and pyrrhotite from Holes $856 \mathrm{G}$ and $856 \mathrm{H}$ at the massive sulfide deposit at Middle Valley, northern Juan de Fuca Ridge. Sample nomenclature, mineralogy, and chemistry are reported in Table 1. A more detailed discussion of the mineralogy and sulfur isotope composition of these samples is presented by Duckworth et al. (this volume). Sample mineralogy given here was determined by powder $\mathrm{X}$-ray diffraction (XRD) at the University of Manchester. 
Table 1. Depth and mineralogy of Site 856 samples.

\begin{tabular}{|c|c|c|c|c|}
\hline \multirow{2}{*}{$\begin{array}{l}\text { Core, section, } \\
\text { interval }(\mathrm{cm})\end{array}$} & \multirow{2}{*}{$\begin{array}{l}\text { Depth } \\
\text { (mbsf) }\end{array}$} & \multicolumn{2}{|r|}{ Mineralogy ${ }^{\|}$} & \multirow{2}{*}{$\begin{array}{c}\text { Pyrite }{ }^{b} \delta^{34} S \\
(\% 0)\end{array}$} \\
\hline & & Major & Minor & \\
\hline \multicolumn{5}{|l|}{$139-856 \mathrm{H}-$} \\
\hline $2 \mathrm{R}-1,4-6$ & 13.54 & Py Sd & $\mathrm{Tc}$ & +1.7 \\
\hline 3R-3, 83-85 & 25.54 & Py Pyh & Sd Go Sep Chl & +5.9 \\
\hline $4 R-2,57-59$ & 28.67 & Py Mag & Pyh Che Chl & $+8.0(+7.6)$ \\
\hline $6 \mathrm{R}-1,32-34$ & 37.72 & Py Mc & Cpy Mag Pyh Cal Dol & $(+5.7)$ \\
\hline $10 \mathrm{R}-1,8-10$ & 57.08 & Py & Cpy Serp Chl & +8.4 \\
\hline $11 \mathrm{R}-1,94-96$ & 62.24 & Py & Cpy Serp & +4.8 \\
\hline $13 \mathrm{R}-1,56-57$ & 71.46 & Py Mc & Mag Sd Pyh Dol Cal & +2.8 \\
\hline $17 \mathrm{R}-1,2-4$ & 90.12 & Py Pyh & Cpy Mag Go Serp ChI & +1.6 \\
\hline $\begin{array}{l}139-856 \mathrm{G}- \\
7 \mathrm{R}-4,6-8\end{array}$ & 60.16 & Py Sph & Cpy Serp & +5.8 \\
\hline
\end{tabular}

${ }^{a} \mathrm{Py}=$ pyrite, $\mathrm{Pyh}=$ pyrnhotite, $\mathrm{Mag}=$ magnetite, $\mathrm{Mc}=$ marcasite, $\mathrm{Sd}=$ siderite, $\mathrm{Cpy}=$ chalcopyrite, $\mathrm{Sph}=$ sphalerite, Chc $=$ chalcocite, Serp $=$ serpentine, $\mathrm{Chl}=$ chlorite, $\mathrm{Cal}=$ calcite, $\mathrm{Dol}=$ dolomite, $\mathrm{Go}=$ goethite, $\mathrm{Tc}=$ talc, Sep $=$ sepiolite.

${ }^{b}$ Values for pyrrhotite are in parentheses; $\delta^{34} \mathrm{~S}$ data are from Duckworth et al. (this volume)

Sulfide minerals were hand-picked from coarsely crushed hand specimens in an attempt to minimize contamination by hydrated minerals. From 300 to $500 \mathrm{mg}$ of 0.5 - to 2 -mm-sized grains were loaded into the extraction apparatus and crushed sequentially in vacuo in a system of on-line crushers to preferentially release noble gases from fluid inclusions. The presence of $\mathrm{H}_{2} \mathrm{O}$ in talc, serpentine, and chlorite required baking all the samples at approximately $200^{\circ} \mathrm{C}$ for 48 hours until the pressure in the crushing apparatus was $<10^{-8}$ torr. Previous experiments have shown that noble gas loss from sulfide minerals at these temperatures is negligible (Turner and Stuart, 1992). The sample weights (Table 2 ) represent the fraction remaining after crushing that passed through a $100-\mu \mathrm{m}$-mesh sieve.

Extraction and gas processing were performed in a low-volume, all-metal line. The gases released were exposed to an SAES NP10 $\mathrm{Al}-\mathrm{Zr}$ getter at $300^{\circ} \mathrm{C}$ for $20 \mathrm{~min}$ to remove the reactive gases. Heavy noble gases were then condensed onto a liquid $\mathrm{N}_{2}$-cooled charcoal finger (VTC 1). Significant quantities of water remained at this stage, and required exposure of the residual gases to a second hot $\mathrm{Al}-\mathrm{Zr}$ getter for a further 10 minutes before analyses of $\mathrm{He}$ and $\mathrm{Ne}$. A cold C50 Ti-Zr getter and a second liquid $\mathrm{N}_{2}$-cooled charcoal finger, adjacent to the spectrometer source, were employed during analysis to minimize the pressures of $\mathrm{H}$ and $\mathrm{Ar}$, respectively. During $\mathrm{He}-\mathrm{Ne}$ analysis the heavy noble gases were released from the VTC 1 at $100^{\circ} \mathrm{C}$ and subsequently admitted to the spectrometer for measurement of $\mathrm{Ar}$ isotopes and the abundances of $\mathrm{Kr}$ and $\mathrm{Xe}$. In many cases, the abundances of the heavy noble gases were too high to measure; those cases are not discussed in detail here.

An all-metal MAP 215 mass spectrometer with a resolving power of $>850$ capable of complete resolution of the ${ }^{3} \mathrm{H}-\mathrm{HD}^{+}$doublet from ${ }^{3} \mathrm{He}^{+}$, was used for noble gas measurements. The low ${ }^{3} \mathrm{He} /{ }^{4} \mathrm{He}$ ratios in nature require measurement of ${ }^{3} \mathrm{He}$ and ${ }^{4} \mathrm{He}$ on electron multiplier and Faraday detectors, respectively. ${ }^{3} \mathrm{He} /{ }^{4} \mathrm{He}$ ratio measurements were calibrated against those made on $1.05 \times 10^{-6} \mathrm{~cm}^{3}$ standard temperature and pressure (STP) air and have an overall reproducibility of $\pm 5 \%$. He/Ne ratios and absolute abundances of ${ }^{4} \mathrm{He}$ and ${ }^{20} \mathrm{Ne}$ were made by peakheight comparison with this same amount of gas and have a reproducibility of $\pm 5 \%(1 \sigma)$. The reproducibility of measuring small volumes of high ${ }^{3} \mathrm{He} /{ }^{4} \mathrm{He}$ gas was monitored by repeated crushes of an internal standard: a gas-rich olivine from a dunite xenolith from Réunion Island, Indian Ocean $\left(\mathrm{R} / \mathrm{R}_{\mathrm{a}}=12.9 \pm 0.06, n=10\right)$. A correction for the effect of ${ }^{40} \mathrm{Ar}^{2+}$ to mass $20(0.2 \pm 0.05)$ was made to ${ }^{20} \mathrm{Ne}$ abundances. Blank measurements were made by crushing inclusion-free quartz and were insignificant relative to gas amounts released by the sulfides.

\section{RESULTS}

${ }^{3} \mathrm{He} /{ }^{4} \mathrm{He}$ ratios and abundances of $\mathrm{He}$ and $\mathrm{Ne}$ of all samples are displayed in Table 2 . He abundances are low compared with those for
Table 2. He and Ne data for Middle Valley sulfides from Site 856.

\begin{tabular}{|c|c|c|c|c|c|}
\hline $\begin{array}{l}\text { Core, section, } \\
\text { interval }(\mathrm{cm})\end{array}$ & $\begin{array}{l}\text { Weight } \\
\text { (g) }\end{array}$ & $\begin{array}{c}4 \mathrm{He} \\
\left(10^{-8} \mathrm{~cm}^{3} / \mathrm{g}\right)\end{array}$ & $\mathrm{R} / \mathrm{R}_{\mathrm{a}}$ & $\begin{array}{c}{ }^{20} \mathrm{Ne} \\
\left(10^{-9} \mathrm{~cm}^{3} / \mathrm{g}\right)\end{array}$ & $\left(\mathrm{R} / \mathrm{R}_{\mathrm{a}}\right)_{\text {cor }}$ \\
\hline \multicolumn{6}{|l|}{$139-856 \mathrm{H}-$} \\
\hline $2 \mathrm{R}-1,4-6$ & 0.134 & $\begin{array}{r}0.16 \\
\pm 0.02\end{array}$ & $\mathrm{~nm}$ & $\mathrm{~nm}$ & $\mathrm{~nm}$ \\
\hline $3 R-3,83-85$ & 0.159 & $\begin{array}{r}0.23 \\
\pm 0.01\end{array}$ & $\begin{aligned} & 4.38 \\
& \pm 0.4\end{aligned}$ & $\mathrm{~nm}$ & $\mathrm{~nm}$ \\
\hline $4 R-2,57-59$ & 0.149 & $\begin{array}{r}0.54 \\
\pm 0.01\end{array}$ & $\begin{array}{c}6.86 \\
\pm 0.5\end{array}$ & $\begin{array}{r}0.7 \\
\pm 0.1\end{array}$ & $\begin{array}{c}7.13 \\
\pm 0.5\end{array}$ \\
\hline $10 \mathrm{R}-1,8-10$ & 0.159 & $\begin{array}{r}2.79 \\
\pm 0.05\end{array}$ & $\begin{array}{c}5.2 \\
\pm 0.28\end{array}$ & $\begin{array}{l}10.7 \\
\pm 0.3\end{array}$ & $\begin{array}{r}5.83 \\
\pm 0.28\end{array}$ \\
\hline $11 \mathrm{R}-1,94-96$ & 0.413 & $\begin{array}{r}3.66 \\
\pm 0.07\end{array}$ & $\begin{array}{r}5.74 \\
\pm 0.2\end{array}$ & $\begin{array}{r}5.5 \\
\pm 0.1\end{array}$ & $\begin{array}{r}5.98 \\
\pm 0.2\end{array}$ \\
\hline $13 \mathrm{R}-1,56-57$ & 0.141 & $\begin{array}{r}0.26 \\
\pm 0.01\end{array}$ & $\begin{array}{r}6.2 \\
\pm 0.5\end{array}$ & $\begin{array}{r}0.4 \\
\pm 0.1\end{array}$ & $\begin{aligned} & 6.48 \\
\pm & 0.5\end{aligned}$ \\
\hline $17 \mathrm{R}-1,2-4$ & 0.481 & $\begin{array}{c}3.3 \\
\pm 0.01\end{array}$ & $\begin{array}{r}6.44 \\
\pm 0.14\end{array}$ & $\begin{array}{r}3.7 \\
\pm 0.2\end{array}$ & $\begin{array}{r}6.65 \\
\pm 0.14\end{array}$ \\
\hline $\begin{array}{l}139-856 \mathrm{G}- \\
7 \mathrm{R}-4,6-8\end{array}$ & 0.152 & $\begin{array}{r}1.61 \\
\pm 0.04\end{array}$ & $\begin{array}{r}5.66 \\
\pm 0.24\end{array}$ & $\begin{array}{r}2.5 \\
\pm 0.1\end{array}$ & $\begin{array}{c}5.9 \\
\pm 0.24\end{array}$ \\
\hline
\end{tabular}

Notes: $\mathrm{R}$ is the measured ${ }^{3} \mathrm{He} /{ }^{4} \mathrm{He}$ ratio, $\mathrm{R}_{\mathrm{a}}$ is the equivalent value for atmosphere $\left(1.4 \times 10^{-6}\right) .\left(R / R_{a}\right)_{c o r}$ is the measured value corrected for atmospheric He by assuming all $\mathrm{Ne}$ is of atmospheric origin using: $\left(\mathrm{R} / \mathrm{R}_{\mathrm{a}}\right)_{\text {cor }}=\left[\left(\mathrm{R} / \mathrm{R}_{\mathrm{a}}\right)_{\text {meas }} \times(\mathrm{X}-1)\right] /[\mathrm{X}-1]$. where $\mathrm{X}=\left({ }^{4} \mathrm{He} /{ }^{20} \mathrm{Ne}\right)_{\text {meax }} /\left({ }^{4} \mathrm{He} /{ }^{20} \mathrm{Ne}\right)_{\text {air }} \mathrm{He}$ and $\mathrm{Ne}$ abundances are subject to a $\pm 5 \%$ uncertainty $(1 \sigma) . \mathrm{nm}=$ not measured.

sulfide minerals from $21^{\circ} \mathrm{N}$ EPR (Stuart et al., 1992; Turner and Stuart, 1992), resulting in imprecise ${ }^{3} \mathrm{He} /{ }^{4} \mathrm{He}$ measurements in a number of cases. Although ${ }^{4} \mathrm{He} /{ }^{2} \mathrm{Ne}$ ratios (2.6 to 9.1) indicate significant He enrichments over the atmospheric gas (0.31), they are lower than those of typical MOR vent fluids (e.g., Lupton et al., 1980; Kennedy, 1988). The highest He abundances were measured from coarsegrained sulfides (Samples 139-856 H-17R-1, 2-4 cm and 139-856H$11 \mathrm{R}-1,94-96 \mathrm{~cm})$. We suppose that the low $\mathrm{He}$ abundances are a result of poor trapping of fluid inclusions by the fine-grained sulfides.

Sulfide ${ }^{3} \mathrm{He} /{ }^{4} \mathrm{He}$ and ${ }^{20} \mathrm{Ne} /{ }^{4} \mathrm{He}$ ratios are plotted in Figure 1 . The data lie slightly below a mixing line between atmospheric $\mathrm{He}$ and a MOR basalt component, indicating the presence of a small amount of radiogenic $\mathrm{He}$ in the trapped fluids. There are three possible sources of the atmospheric component: air contamination, modified seawater in fluid inclusions, and atmospheric gases in hydrated minerals. Minor amounts of air-derived noble gases are present in many analyses of solid samples (e.g., Böhlke et al., 1989; Böhlke and Irwin, 1992; Turner and Stuart, 1992). These noble gases may be adsorbed onto fresh mineral surfaces or implanted during sample preparation. It is difficult to determine the origin of the atmosphere-like component using light noble gas data alone. However, a correction for the atmospheric component can be made to the helium isotope data using the measured $\mathrm{He} / \mathrm{Ne}$ ratio (Table 2). Because the solubilities of $\mathrm{He}$ and $\mathrm{Ne}$ in water within the expected temperature and salinity ranges are similar, the corrected ${ }^{3} \mathrm{He} /{ }^{4} \mathrm{He}$ ratios are insensitive to the origin of the atmospheric gases.

Corrected ${ }^{3} \mathrm{He} /{ }^{4} \mathrm{He}$ ratios range between 5.8 and $7.1 \mathrm{R}_{\mathrm{a}}$. Using end-member values of $8.4 \mathrm{R}_{\mathrm{a}}$ for MOR basalt $\mathrm{He}$ (Trull et al., 1990) and $0.02 \mathrm{R}_{\mathrm{a}}$ for radiogenic He produced in deep-sea sediments (Sano and Wakita, 1986) between $15 \%$ and $33 \%$ of the ${ }^{4} \mathrm{He}$ in these samples is of radiogenic origin. ${ }^{3} \mathrm{He} /{ }^{4} \mathrm{He}$ ratios are plotted in Figure 2 along with data from submarine hydrothermal vent waters, $21^{\circ} \mathrm{N}$ EPR sulfides, and oceanic basalts. The measured $\mathrm{He}$ isotope ratios are below those of vent fluids from the Juan de Fuca Ridge (see Lupton et al., 1989). The young age of the Middle Valley sulfide deposit rules out in-situ ${ }^{4} \mathrm{He}$ as an important contribution in these samples.

${ }^{3} \mathrm{He} /{ }^{4} \mathrm{He}$ ratios of submarine vent fluids are commonly slightly lower than those of nearby basalts (e.g., Kennedy, 1988; Kodera et al., 1988; but see Craig and Lupton, 1981). Differences in the ${ }^{3} \mathrm{He} /{ }^{4} \mathrm{He}$ ratios of MOR basalts and hydrothermal fluids venting along the Juan de Fuca Ridge have been suggested to result from the addition of radiogenic ${ }^{4} \mathrm{He}$ (here termed ${ }^{4} \mathrm{He}_{\mathrm{RAD}}$ ) to hydrothermal fluids during seawater circulation in the oceanic crust (Kennedy, 1988). However, 


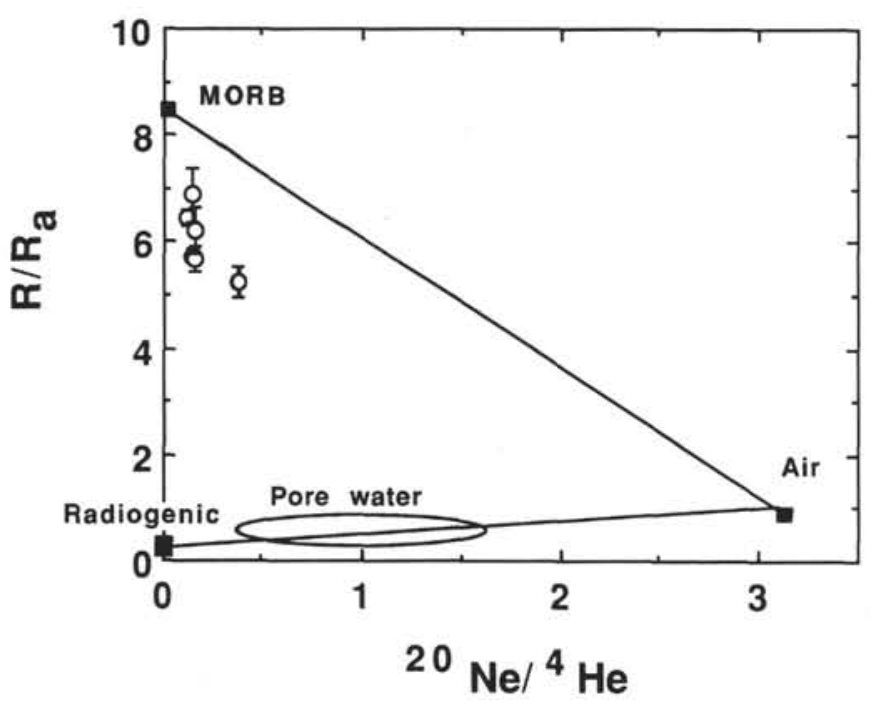

Figure 1. Air-normalized He isotope ratios $\left(\mathrm{R} / \mathrm{R}_{\mathrm{a}}\right)$ and ${ }^{20} \mathrm{Ne} /{ }^{4} \mathrm{He}$ ratios for Middle Valley sulfides. The Middle Valley data are displayed as open circles; end-member noble gas components (air, MORB, and radiogenic) are filled squares. The mixing line is drawn between air $\left(R / R_{a}=1\right)$ and MORB $\left(R / R_{a}=\right.$ $8.4,{ }^{20} \mathrm{Ne} /{ }^{4} \mathrm{He}=5 \times 10^{-5}$ : "popping rock" from Staudacher et al., 1989). The data plot slightly below the mixing line, indicating that although the mantlederived component dominates, the fluid $\mathrm{He}$ was diluted by measurable amounts of radiogenic $\mathrm{He}\left(\mathrm{R} / \mathrm{R}_{\mathrm{a}}=0.02\right.$; Sano and Wakita, 1986). Sediment pore-water values are from Sano and Wakita (1986).

the possibility that this is an experimental artifact caused by interlaboratory bias in $\mathrm{He}$ isotope measurements cannot yet be discounted.

The ${ }^{3} \mathrm{He} /{ }^{4} \mathrm{He}$ ratios of the Middle Valley sulfides overlap those recorded for methane-rich submarine vent waters from the southern trough of Guaymas Basin, Gulf of California (7 $R_{a}$; Lupton, 1983b). The low value of ${ }^{3} \mathrm{He} /{ }^{4} \mathrm{He}$ for Guaymas Basin vent fluids may be due to the leaching of ${ }^{4} \mathrm{He}_{\text {RAD }}$ produced by radiogenic decay of $\mathrm{U}$ and $\mathrm{Th}$ in the cap of overlying impermeable sediments (Lupton, 1983b). Although it is not known whether the massive sulfide deposit at Site 856 sits atop sediments or basement, drilling at Site 857 nearby revealed $471 \mathrm{~m}$ of sediment overlying a sediment-sill complex. The sediment thicknesses are comparable to that at Guaymas Basin and act as an effective barrier to heat loss and fluid upwelling (Davis and Villinger, 1992). The presence of a thick sedimentary cover at both Guaymas Basin and Middle Valley hydrothermal systems suggests that the low ${ }^{3} \mathrm{He} /{ }^{4} \mathrm{He}$ signature of fluids at both ridge crests may be the result of similar processes, so that comparisons on the basis of $\mathrm{He}$ isotopes are justified. More extensive water-rock interaction or longer fluid residence time in the source region may explain the lower ${ }^{3} \mathrm{He} /{ }^{4} \mathrm{He}$ ratios of vent fluids in Middle Valley and Guaymas Basin.

\section{DISCUSSION}

\section{Helium Sources}

Fluids venting along the Juan de Fuca Ridge have ${ }^{3} \mathrm{He} /{ }^{4} \mathrm{He}$ ratios typical of the global mid-ocean ridge system (7.8 to 8.4; Lupton et al., 1989). The low ${ }^{3} \mathrm{He} /{ }^{4} \mathrm{He}$ ratios in fluid inclusions within Middle Valley sulfides must result from the addition of radiogenic ${ }^{4} \mathrm{He}$ to typical MOR vent fluids. Downhole measurements of Hole $856 \mathrm{H}$ record a 10 -m-thick layer that displays high radioactivity within the sulfide pile (Davis, Mottl, Fisher, et al., 1992). Thus, the hydrothermal fluids have acquired, transported, and deposited significant quantities of radio-elements. Two mechanisms may explain the radiogenic helium component of the Middle Valley hydrothermal fluids: (1) seawater interaction with an aged magmatic system, and (2) sedimentary pore fluids. Both of these potential sources are assessed below.
Radiogenic

Primordial

\begin{tabular}{|c|c|}
\hline$\mapsto$ & $\begin{array}{l}\text { Deep-sea sediment } \\
\text { pore fluids }\end{array}$ \\
\hline $\begin{array}{l}\text { Middle Valley } \\
\text { sulfides }\end{array}$ & $\mapsto$ \\
\hline $\begin{array}{l}\text { Guaymas Basin } \\
\text { vent fluids }\end{array}$ & - \\
\hline $\begin{array}{l}21^{\circ} \mathrm{N} \text { EPR } \\
\text { sulfides }\end{array}$ & - \\
\hline MOR basalts & - \\
\hline MOR vent fluids & = \\
\hline $\begin{array}{l}\text { Loihi seamount } \\
\text { vent fluids }\end{array}$ & 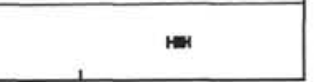 \\
\hline 1 & 10 \\
\hline
\end{tabular}

Figure 2. Ranges of helium isotope compositions of oceanic hydrothermal fluids and basalts, and of deep-sea sediment pore fluids. Middle Valley sulfides $\left(\mathrm{R} / \mathrm{R}_{\mathrm{a}}=5.8\right.$ to 7.1$)$ are more radiogenic than those of typical MOR fluids. Data sources: Loihi seamount (Kodera et al., 1988); mid-ocean ridge basalts (average from Trull et al., 1990); MOR vent fluids (Lupton et al., 1989); Guaymas Basin vent fluids (Lupton, 1983a); $21^{\circ} \mathrm{N}$ EPR sulfides (Turner and Stuart, 1992); and deep-sea sediment pore fluids (Sano and Wakita, 1986).

\section{Magma Aging}

Degassing of MOR magmas is expected to increase the $(\mathrm{U}+\mathrm{Th}) /$ He ratio of the residual magma. The subsequent decay of $U$ and Th reduces the ${ }^{3} \mathrm{He} /{ }^{4} \mathrm{He}$ ratio of the remaining volatiles below typical MOR values (Zindler and Hart, 1986). This mechanism may account for low ${ }^{3} \mathrm{He} /{ }^{4} \mathrm{He}$ ratios $\left(\sim 1 \mathrm{R}_{\mathrm{a}}\right)$ measured in alkali basalts from seamounts close to the East Pacific Rise at $12^{\circ} \mathrm{N}$ (Graham et al., 1988).

The tectonic style of the northern Juan de Fuca Ridge is complex and differs from the typical ridge-crest morphology displayed by much of the ridge. Spreading along the northern end of the Juan de Fuca Ridge is accommodated by three en-echelon axial rifts (West, Endeavour, and Middle Valley). This results from the aging of the magmatic system near the anomalously cool Sovanco Transform Fault to the north (Davis, Mottl, Fisher, et al., 1992) and may be important in supplying low ${ }^{3} \mathrm{He} / 4 \mathrm{He}$ basalts to the axial rifts of the northern Juan de Fuca Ridge. If the radiogenic helium originates from water-rock interaction in the vicinity of the magma chamber, then the fluid ${ }^{3} \mathrm{He} /{ }^{4} \mathrm{He}$ reflects the $\mathrm{He}$ isotope composition of the source-rock. Source-rock ${ }^{3} \mathrm{He} /{ }^{4} \mathrm{He}$ decrease through time can be modelled using the conventional decay equations. On short time scales $\left(<10^{7} \mathrm{yr}\right)$, the fractional change in ${ }^{3} \mathrm{He} /{ }^{4} \mathrm{He}$ with time is represented by a factor $f_{3 / 4}$ given by:

$$
f_{3 / 4}=1-\left[t \times 2.179 \times 10^{-13} \times\left(\mathrm{U} /{ }^{4} \mathrm{He}\right)\right],
$$

where $t$ is the age in years, $\mathrm{U}$ is the uranium concentration in ppm (and $\mathrm{Th} / \mathrm{U}=3.5$ ), and ${ }^{4} \mathrm{He}$ is measured in $\mathrm{cm}^{3} \mathrm{STP} / \mathrm{g}$ (Zindler and Hart, 1986). U and Th contents of normal mid-ocean ridge basalts (MORB) are low $(0.02-0.13 \mathrm{ppm} \mathrm{U}$ and $0.03-0.4 \mathrm{ppm} \mathrm{Th}$, respectively; Jochum et al., 1983) and generate $0.3-2.7 \times 10^{-14} \mathrm{~cm}^{3}$ STP ${ }^{4} \mathrm{He}_{\mathrm{RAD}} / \mathrm{g} / \mathrm{yr}$. The average $\mathrm{U} /{ }^{4} \mathrm{He}$ ratio of MOR basalts of $\sim 6000$ is significantly higher than that proposed for the MORB mantle (630), and indicates that MORB magmas are highly degassed (Zindler and Hart, 1986). To reduce the basalt ${ }^{3} \mathrm{He} /{ }^{4} \mathrm{He}$ ratio from $8.4 \mathrm{R}_{\mathrm{a}}$ (the typical MORB value; Trull et al., 1990) to $7.1 \mathrm{R}_{\mathrm{a}}$ (the maximum value of Middle Valley sulfides) requires that the hydrothermal fluids interacted with oceanic crust for $>130 \mathrm{Ma}$. For a spreading rate of $6 \mathrm{~cm} / \mathrm{yr}$ for the Juan de Fuca Ridge the fluid source region is therefore $7800 \mathrm{~km}$ 


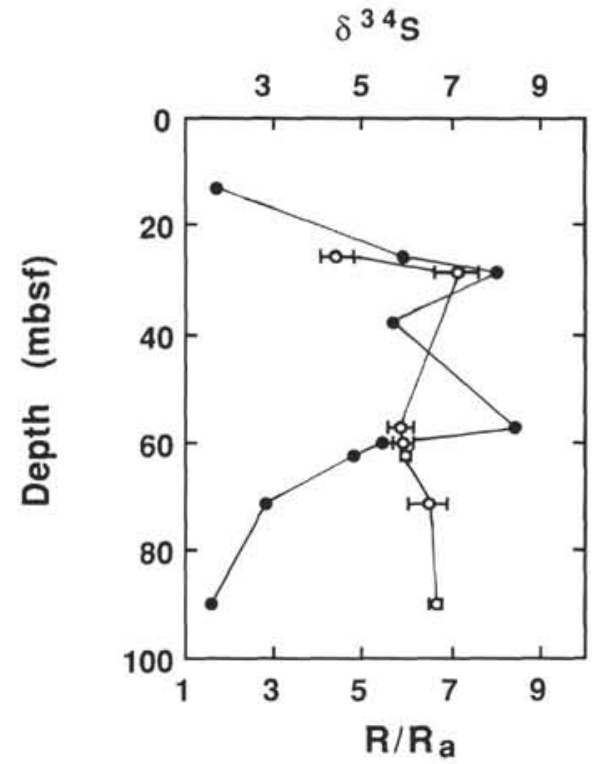

Figure 3. Sulfide $\mathrm{R} / \mathrm{R}_{\mathrm{a}}$ (open circles) and $\delta^{34} \mathrm{~S}$ (filled circles) variation with depth in Hole $856 \mathrm{H}$. Note that the shallowest sample, with the lowest ${ }^{3} \mathrm{He} /{ }^{4} \mathrm{He}$ ratio, is not air corrected.

off-ridge, which is clearly unreasonable. Geologic considerations and the position of Middle Valley relative to the Brunhes magnetic Chron indicates that the sediment-covered axial ridge is less than a few hundred thousand yr old (Davis and Villinger, 1992). The low ${ }^{3} \mathrm{He} /{ }^{4} \mathrm{He}$ ratios measured here therefore cannot be due to the extraction of radiogenic $\mathrm{He}$ from ancient basaltic crust.

An alternative may be that the low ${ }^{3} \mathrm{He} /{ }^{4} \mathrm{He}$ volatiles are extracted from the magma itself. The necessary reduction of magmatic ${ }^{3} \mathrm{He} /{ }^{4} \mathrm{He}$ ratios occurs when the product $\left(\mathrm{U} /{ }^{4} \mathrm{He}\right) t>4 \times 10^{12}$. If the Middle Valley magmatic system is 300,000 yr old (Davis and Villinger, 1992), the required lowering of magmatic ${ }^{3} \mathrm{He} /{ }^{4} \mathrm{He}$ ratios will only occur when $\left(\mathrm{U} /{ }^{4} \mathrm{He}\right)_{\text {magma }}>1.3 \times 10^{7}$. Such high $\mathrm{U} /{ }^{4} \mathrm{He}$ ratios are three orders of magnitude higher than that of typical MORB, and are possible in extensively degassed magmas (Zindler and Hart, 1986). This places restrictions on the degree to which magmatic $\mathrm{He}$ will be extracted by circulating hydrothermal fluids. The fluids resulting from seawater interaction with a degassed magma will have $\mathrm{He} / \mathrm{Ne}$ ratios significantly lower than those of fluids venting from presently active spreading ridges. The low $\mathrm{He} / \mathrm{Ne}$ ratios measured here are consistent with this scenario for Middle Valley, but may merely reflect a significant atmospheric component in the solid samples.

\section{Sedimentary Pore Fluids}

The coincidence of abnormally low ${ }^{3} \mathrm{He} /{ }^{4} \mathrm{He}$ ratios and thick sedimentary sequences in both the Guaymas Basin and Middle Valley hydrothermal systems is circumstantial evidence that the sediments act as a source of ${ }^{4} \mathrm{He}_{\text {RAD }}$. In this case, the measured $\mathrm{He}$ in the fluids is a mixture of a high ${ }^{3} \mathrm{He} /{ }^{4} \mathrm{He}$ MOR component (similar to that seen in MOR vent fluids) and a radiogenic component derived from the sediments.

Radio-elements are enriched in ocean-floor sediments by more than 10 times compared to pristine MOR basalts $(\mathrm{U}=2.6 \mathrm{ppm}$ and $\mathrm{Th}$ $=13.5 \mathrm{ppm}$; Taylor and McLennan, 1985). In-situ decay of U and Th in deep-sea sediments produces $7 \times 10^{-13} \mathrm{~cm}^{3} \mathrm{STP}^{4} \mathrm{He}_{\mathrm{RAD}} / \mathrm{g} / \mathrm{yr}$. He abundances and isotope ratios of ocean floor sediments are variable and are the result of mixing between in-situ radiogenic $\mathrm{He}$ and extraterrestrial He from interplanetary dust particles (IDP) (e.g., Takayanagi and Ozima, 1987). Sediments sampled close to continental margins, where sedimentation rates are high, are characterized by radiogenic $\mathrm{He}$ (Sano and Wakita, 1986). The thick sequence of turbidites in Middle Valley attests to high sedimentation rates during the Pleistocene and Holocene and implies that sediment ${ }^{3} \mathrm{He} /{ }^{4} \mathrm{He}$ ratios are low.

If all of the measured $\mathrm{Ne}$ is derived from Pacific deep waters, ${ }^{4} \mathrm{He}_{\mathrm{RAD}}$ concentrations in the trapped hydrothermal fluids are in the range $2.2-3.8 \times 10^{-7} \mathrm{~cm}^{3} \mathrm{STP} / \mathrm{cm}^{3}$. Concentrations of radiogenic $\mathrm{He}$ in deep-sea sediments are typically $3 \times 10^{-7} \mathrm{~cm}^{3} \mathrm{STP} / \mathrm{g}$ (Takayanagi and Ozima, 1987). If ${ }^{4} \mathrm{He}_{\mathrm{RAD}}$ is quantitatively extracted from the sediments by the circulating hydrothermal fluids, then water-sediment ratios must approach unity. It is probable that a proportion of the measured $\mathrm{Ne}$ (and $\mathrm{He}$ ) is not derived from the fluid inclusions but is from some atmospheric contamination, either from adsorbed/ implanted air or from hydrated minerals. Thus, the calculated ${ }^{4} \mathrm{He} \mathrm{RAD}_{\mathrm{R}}$ concentrations for Middle Valley must be treated as maxima.

Localized, lateral flow of $\sim 200^{\circ} \mathrm{C}$ hydrothermal solutions through permeable sedimentary layers that was inferred following drilling of the active hydrothermal system suggests that there may be extensive sediment-fluid interaction in this type of ridge environment. However, the sulfide mineralogy at Middle Valley is identical to that of typical MOR hydrothermal sites (Duckworth et al., this volume). In particular, the Middle Valley sulfides lack enrichments in $\mathrm{Pb}, \mathrm{As}, \mathrm{Sb}$, etc., that identify significant high-temperature fluid-sediment interaction (Koski et al., 1988). Radiogenic He may have been present before basalt-fluid interaction at depth, if the recharging fluid was partly derived from the overlying turbidite pore waters. The $\mathrm{U}, \mathrm{Th}$, and $\mathrm{He}$ contents of the sediments beneath the sulfide body at Middle Valley are presently unknown as drilling did not fully penetrate the deposit. Further work is required to determine whether the deep sediments can supply sufficient radiogenic ${ }^{4} \mathrm{He}$ to lower MOR ${ }^{3} \mathrm{He} /{ }^{4} \mathrm{He}$ ratios to those measured in the sulfides.

\section{${ }^{3} \mathrm{He} /{ }^{4} \mathrm{He}-\delta^{34} \mathrm{~S}$ Relationships}

The lack of sedimentary layers within the Middle Valley massive sulfide deposit suggests that mineralization occurred directly on the seafloor, rather than at the sediment/basalt interface. If so, the sulfide "stratigraphy" may record the evolution of the hydrothermal fluids with time. Increasing ${ }^{3} \mathrm{He} /{ }^{4} \mathrm{He}$ ratios with depth (Fig. 3) may imply that water-sediment ratios decreased or fluid residence times increased during mineralization. From the limited number of samples analyzed, no clear trend is evident from Figure 3. It is interesting to note, however, that the lowest ${ }^{3} \mathrm{He} /{ }^{4} \mathrm{He}$ ratios occur between approximately 60 and $70 \mathrm{mbsf}$, in a zone that has the highest $\delta^{34} \mathrm{~S}$ values. Unfortunately, the large error on many ${ }^{3} \mathrm{He} /{ }^{4} \mathrm{He}$ measurements may be partly responsible for obscuring possible subtle trends in these data.

The ${ }^{3} \mathrm{He} /{ }^{4} \mathrm{He}$ variations in the sulfide fluids from Middle Valley are consistent with mixing variable proportions of a high ${ }^{3} \mathrm{He} /{ }^{4} \mathrm{He}$ basaltic component with a low ${ }^{3} \mathrm{He} /{ }^{4} \mathrm{He}$ radiogenic component derived from the sediment pore waters. Such mixing is commonly invoked to explain variations of ${ }^{3} \mathrm{He} /{ }^{4} \mathrm{He}$ in hydrothermal fluids from the continental crust (e.g., Kennedy et al., 1985). The ${ }^{3} \mathrm{He} /{ }^{4} \mathrm{He}$ ratios of the end-members may be assumed to be constant. Variation in the resultant fluid ${ }^{3} \mathrm{He} /{ }^{4} \mathrm{He}$ ratios may be generated by mixing different proportions of the end-member fluid components, or changes in the He concentration of the end members varies. Temporal variations to the supply of the fluids might occur as a result of changes in fluid pathways. This may occur in response to fracturing, controlled by seismic/magmatic events, or to blockage by mineral precipitation. He concentrations of MOR vent fluids vary spatially and temporally in response to processes occurring deep within the magmatic system, e.g., boiling (Butterfield et al., 1990) and melt replenishment (Lupton et al., 1989). A decrease in the flux of basalt-derived volatiles is expected as the magmatic system ages, increasing the relative importance of the other helium source-rocks, e.g., the sedimentary pore fluids, and would be reflected in a progressive decrease of ${ }^{3} \mathrm{He} /{ }^{4} \mathrm{He}$ through time.

The $\delta^{34} \mathrm{~S}_{\mathrm{CDT}}$ values of the Middle Valley sulfides, analyzed for $\mathrm{He}$, range from $+1.6 \%$ to $+8.4 \%$ (Table 1 ). Pyrite is the dominant $\mathrm{Fe}$ sulfide present; pyrrhotite was analyzed in only two cases. The values 
reported here are significantly higher than those for sulfides from typical sediment-free ridge crests. For example, $\delta^{34} \mathrm{~S}$ values of sulfides at $21^{\circ} \mathrm{N}$ EPR range from $+1 \%$ and $+4 \%$ (Woodruff and Shanks, 1988 , and references therein). Values heavier than $+4 \%$ are explained either by the replacement of sulfate by sulfide (Shanks and Seyfried, 1987), or by the entrainment of seawater by the hydrothermal fluids (Woodruff and Shanks, 1988). The sulfate required for the high values measured at Middle Valley may be derived from ambient seawater, seawater-dominated pore fluids in the sediments, or directly from sedimentary sulfate.

Pyrite $\delta^{34} \mathrm{~S}$ values are plotted against ${ }^{3} \mathrm{He} /{ }^{4} \mathrm{He}$ in Figure 4, along with data from $21^{\circ} \mathrm{N}$ EPR. No clear relationship between $\mathrm{He}$ and $\mathrm{S}$ isotopes is evident from the Middle Valley data alone, but they display a broad negative trend when combined with the data from $21^{\circ} \mathrm{N}$ EPR. ${ }^{3} \mathrm{He} /{ }^{4} \mathrm{He}$ ratios from the $21^{\circ} \mathrm{N}$ EPR sulfides are similar to those of MOR vent fluids $\left(7.8 \pm 0.2 R_{a}\right)$ and accompany typical ridge-crest sulfur isotope ratios $(+1 \%$ to $+3.5 \%$; Stuart et al., 1992). The radiogenic helium in the Middle Valley inclusion fluids correlates with high $\delta^{34} S_{\text {pyrite }}$ values, which have been explained as being due to the presence of sedimentary pore fluid sulfur in the evolving hydrothermal stockwork zone (Duckworth et al., this volume). The lack of a close correlation with $\mathrm{He}$ indicates that the processes controlling ${ }^{3} \mathrm{He} /{ }^{4} \mathrm{He}$ and $\delta^{34} \mathrm{~S}$ variations are decoupled locally. However, the broad trend implies that both processes operate at Middle Valley and provides strong evidence for the role of sediments in the lowering of ${ }^{3} \mathrm{He} /{ }^{4} \mathrm{He}$ ratios of fluids in hydrothermal systems of in sediment-covered ridge crests. Investigations of the trapped fluids at this and other sedimentcovered ridge hydrothermal systems (e.g., Escanaba Trough, Gorda Ridge) is clearly required to assess the validity of this relationship. Such investigations are currently underway.

\section{Heavy Noble Gas Abundances and Absolute He Concentrations}

The heavy noble gas abundances of Middle Valley sulfides (data not included herein) are 10 to 50 times higher than those measured in ocean-floor sulfides from $21^{\circ} \mathrm{N}$ EPR (Turner and Stuart, 1992). This intuitively suggests that a significant contribution of air-derived noble gases are present in the Middle Valley sulfides. Ar and Xe isotope ratios are indistinguishable from the air values. XRD analyses indicate that hydrated minerals such as chlorite, serpentine, and talc are present in all of our samples (Table 1). These are not sedimentary in origin, but formed late in the evolution of the system when vent fluids mixed with seawater during hydrothermal reworking. Hydrated phyllosilicates are known to trap high concentrations of $\mathrm{Ar}, \mathrm{Kr}$, and $\mathrm{Xe}$ (Podosek et al., 1980) as a result of solution and/or adsorption of atmospheric gases. In a data compilation, Ozima and Podosek (1983) failed to identify any consistent abundance pattern from sedimentary rocks except a general trend of enrichment of heavy noble gases. The difficulty experienced in pumping/cleaning these samples and the high concentrations of $\mathrm{Ar}, \mathrm{Kr}$, and $\mathrm{Xe}$ suggest that the heavy noble gases are associated with the hydrated minerals. We note that the release of the heavy noble gases by crushing requires that they are only loosely bound to the hydrated minerals.

The results presented here contrast with those obtained for fluid inclusions in sulfides from $21^{\circ} \mathrm{N}$ EPR (Turner and Stuart, 1992). Turner and Stuart (1992) reported that He/Ar ratios, corrected for the presence of small volumes of air using $\mathrm{Kr} / \mathrm{Ar}$ ratios, were close to the values measured in the vent fluids. Studies of noble gases in fluid inclusions in pure mineral separates (e.g., Böhlke et al., 1989; Böhlke and Irwin, 1992; Stuart et al., unpubl. data) suggest that, to a first order, $\mathrm{Ne}-\mathrm{Ar}-\mathrm{Kr}$ abundances are consistent with this mixing relationship. This cannot be extended to samples where fine-grained, hydrated minerals are present, however. This rules out the determination of absolute concentrations of helium in the fluids and emphasizes the necessity of careful sample selection in the study noble gases dissolved in fluid inclusions.

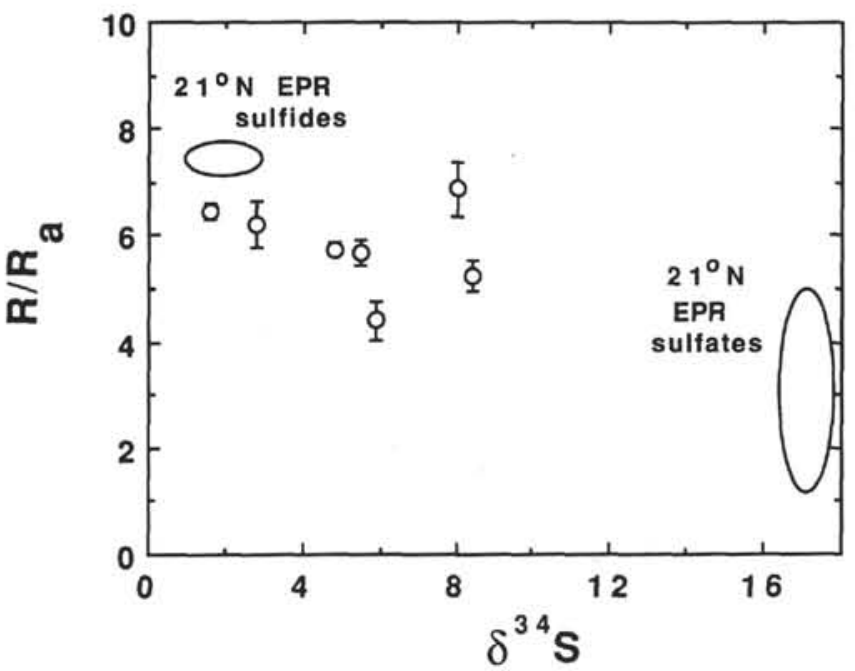

Figure 4. R/R $\mathrm{R}_{\mathrm{a}}$ vs. $\delta^{34} \mathrm{~S}$ for Middle Valley sulfides. The data overlap those for sulfides from $21^{\circ} \mathrm{N}$ East Pacific Rise, a typical mid-ocean ridge setting, and display a broad negative correlation that implies that the processes controlling $\mathrm{He}$ and $\mathrm{S}$ isotope variation in MOR hydrothermal systems are linked. Data for $21^{\circ} \mathrm{N}$ EPR sulfides are from Stuart et al. (1992).

\section{SUMMARY}

Sulfide minerals from Site 856 of ODP Leg 139 precipitated from fluids that are enriched in mantle-derived $\mathrm{He}$. Air-corrected ${ }^{3} \mathrm{He} /{ }^{4} \mathrm{He}$ ratios $\left(5.8\right.$ to $7.1 \mathrm{R}_{\mathrm{a}}$ ) are lower than typical mid-ocean ridge vent fluids $\left(\sim 8 \mathrm{R}_{\mathrm{a}}\right)$. This is due to the addition of radiogenic He either during seawater circulation in the aging magmatic system beneath Middle Valley, or from the overlying sediments. In conjunction with data from sediment-free MOR sites, the ${ }^{3} \mathrm{He} /{ }^{4} \mathrm{He}$ and $\delta^{34} \mathrm{~S}$ data suggest a broad negative correlation between $\mathrm{He}$ and $\mathrm{S}$ isotopes in oceanfloor hydrothermal systems. The isotopically heavy sulfur must originate in the sediments, either from the sedimentary pore fluids or the sediments directly, and implies that the radiogenic helium component is sedimentary in origin. Unfortunately, ${ }^{3} \mathrm{He} /{ }^{4} \mathrm{He}$ measurements are not sufficiently precise to draw conclusions about the evolution of the hydrothermal system.

\section{ACKNOWLEDGMENTS}

As ever we thank Dave Blagburn for his technical expertise (and cheery good humor) in the isotope laboratory. Thanks to Paul Harrop for XRD analyses. John Slack, Mack Kennedy, Andrew Fisher, and an anonymous reviewer provided many comments that have improved this manuscript. Noble gas work at the University of Manchester was funded by NERC.

\section{REFERENCES}

Allègre, C.J., Staudacher, T., Sarda, P., and Kurz, M., 1983. Constraints on the evolution of the Earth's mantle from rare gas systematics. Nature, 303:762-766.

Baker, E.T., and Lupton, J.E., 1990. Changes in submarine hydrothermal ${ }^{3} \mathrm{He} /$ heat ratios as an indicator of magmatic/tectonic activity. Nature, 346:556-558.

Baker, E.T., Massoth, G.J., and Feely, R.A., 1987. Cataclysmic hydrothermal venting on the Juan de Fuca Ridge. Nature, 329:149-151.

\footnotetext{
"Abbreviations for names of organizations and publications in ODP reference lists follow the style given in Chemical Abstracts Service Source Index (published by American Chemical Society).
} 
Böhlke, J.K., and Irwin, J.J., 1992. Laser-microprobe analyses of noble gas isotopes and halogens in fluid inclusions: analyses of microstandards and synthetic inclusions in quartz. Geochim. Cosmochim. Acta, 56:187-201.

Böhlke, J.K., Kirschbaum C., and Irwin, J.J., 1989. Simultaneous analyses of noble gas isotopes and halogens in fluid inclusions in neutron-irradiated quartz veins by use of a laser-microprobe noble-gas mass spectrometer. In Shanks, W.C., III, and Criss, R.E. (Eds.), New Frontiers in Stable Isotope Research. U.S. Geol. Surv. Bull., 1890:61-88.

Butterfield, D.A., Massoth, G.J., McDuff, R.E., Lupton, J.E., and Lilley, M.D., 1990. Geochemistry of hydrothermal fluids from Axial Seamount Hydrothermal Emissions Study vent field, Juan de Fuca: subseafloor boiling and subsequent fluid-rock interaction. J. Geophys. Res., 95:12895-12921.

Craig, H., Clarke, W.B., and Beg, M.A., 1975. Excess ${ }^{3} \mathrm{He}$ in deep water on the East Pacific Rise. Earth Planet. Sci. Lett., 26:125-134.

Craig, H., and Lupton, J.E., 1981. Helium-3 and mantle volatiles in the ocean and the oceanic crust. In Emiliani, C. (Ed.), The Sea (Vol. 7): The Oceanic Lithosphere: New York (Wiley), 391-428.

Davis, E.E., Mottl, M.J., Fisher, A.T., et al., 1992. Proc. ODP, Init. Repts., 139: College Station, TX (Ocean Drilling Program).

Davis, E.E., and Villinger, H., 1992. Tectonic and thermal structure of the Middle Valley sedimented rift, northern Juan de Fuca Ridge. I $n$ Davis, E.E., Mottl, M.J., Fisher, A.T., et al., Proc. ODP, Init. Repts., 139: College Station, TX (Ocean Drilling Program), 9-41.

Graham, D.W., Zindler, A., Kurz, M.D., Jenkins, W.J., Batiza, R., and Staudigel, $\mathrm{H} ., 1988$. $\mathrm{He}, \mathrm{Pb}, \mathrm{Sr}$, and $\mathrm{Nd}$ isotope constraints on magma genesis and mantle heterogeneity beneath young Pacific seamounts. Contrib. Mineral. Petrol., 99:446-463.

Horibe, Y., Kim, K., and Craig, H., 1983. Off-ridge hydrothermal vents: back-arc spreading centers and hot spot seamount. Eos, 64:724.

Jenkins, W.J., Edmonds, J.M., and Corliss, J.B., 1978. Excess ${ }^{3} \mathrm{He}$ and ${ }^{4} \mathrm{He}$ in Galapagos submarine hydrothermal waters. Nature, 272:156-159.

Jochum, K.P., Hofmann, A.W., Ito, E., and White, W.M., 1983. K, U and Th in mid-ocean ridge basalt glasses and heat production, $\mathrm{K} / \mathrm{U}$ and $\mathrm{K} / \mathrm{Rb}$ in the mantle. Nature, 306:431-436.

Kennedy, B.M., 1988. Noble gases in vent water from the Juan de Fuca Ridge. Geochim. Cosmochim. Acta, 52:1929-1935.

Kennedy, B.M., Lynch, M.A., Reynolds, J.H., and Smith, S.P., 1985. Intensive sampling of noble gases in fluids at Yellowstone, I. Early overview of the data. Geochim. Cosmochim. Acta, 49:1251-1261.

Kodera, M., Igarashi, G., and Ozima, M., 1988. Noble gases in hydrothermal plumes of Loihi Seamount. Earth Planet. Sci. Lett., 87:266-272.

Koski, R.A., Shanks, W.C., III, Bohrson, W.A., and Oscarson, R.L., 1988. The composition of massive sulfide deposits from the sediment-covered floor of Escanaba Trough, Gorda Ridge: implications for depositional processes. Can. Mineral., 26:655-673.

Kurz, M.D., Jenkins, W.J., Schilling, J.G., and Hart, S.R., 1982. Helium isotope variations in the mantle beneath the central North Atlantic Ocean. Earth Planet. Sci. Lett., 58:1-14.

Le Cloarec, M.-F., and Marty, B., 1991. Volatile fluxes from volcanoes. Terra Nova, 3:17-27.

Lupton, J., 1979. Helium-3 in the Guaymas Basin: evidence for injection of mantle volatiles in the Gulf of California. J. Geophys. Res., 84:7446-7454. , 1983a. Terrestrial inert gases: isotope tracer studies and clues to primordial components in the mantle.Annu. Rev. Earth Planet. Sci., 11:371-414. 1983b. Fluxes of 3-Helium and heat from submarine hydrothermal systems: Guaymas Basin versus $21^{\circ} \mathrm{N}$ EPR. Eos, 64:723.

Lupton, J., and Craig, H., 1975. Excess ${ }^{3} \mathrm{He}$ in oceanic basalts: evidence for terrestrial primordial helium. Earth Planet. Sci. Lett., 26:133-139.

Lupton, J., Klinkhammer, G.P., Normark, W.R., Haymon, R., Macdonald, K.C., Weiss, R.F., and Craig, H., 1980. Helium-3 and manganese at the $21^{\circ} \mathrm{N}$ East Pacific Rise hydrothermal site. Earth Planet. Sci. Lett., 50:115-127.

Lupton, J.E., Baker, E.T., and Massoth, G.J., 1989. Variable ${ }^{3} \mathrm{He} /$ heat ratios in submarine hydrothermal systems: evidence from two plumes over the Juan de Fuca Ridge. Nature, 337:161-163.

Morrison, P., and Pine, J., 1955. Radiogenic origin of the helium isotopes in rocks. Ann. N.Y. Acad. Sci., 62:71-92.

Ozima, M., and Podosek, F.A., 1983. Noble Gas Geochemistry: Cambridge (Cambridge Univ. Press).

Podosek, F.A., Honda, M., and Ozima, M., 1980. Sedimentary noble gases. Geochim. Cosmochim. Acta, 442:1875-1884.

Sano, Y., and Wakita, H., 1986. ${ }^{3} \mathrm{He} /{ }^{4} \mathrm{He}$ ratios of pore gases in pore waters, Sites 583 and 584. In Kagami, H., Karig, D.E., Coulbourn, W.T., et al., Init. Repts. DSDP, 87: Washington (U.S. Govt. Printing Office), 861-864.

Shanks, W.C., III, and Seyfried, W.E., Jr., 1987. Stable isotope studies of vent fluids and chimney minerals, southern Juan de Fuca Ridge: sodium metasomatism and seawater sulfate reduction. J. Geophys. Res., 92:1138711399.

Staudacher, T., Sarda, P., Richardson, S.H., Allegré, C.J., Sagna, I., and Dimitriev, L.V., 1989. Noble gases in basalt glasses from a Mid-Atlantic Ridge topographic high at $14^{\circ} \mathrm{N}$ : geodynamic consequences. Earth Planet. Sci. Lett., 96:119-133.

Stuart, F.M., Turner, G., and Maynard, J., 1992. The isotopic composition of helium and sulphur in hydrothermal fluids trapped in ancient and modern sea floor deposits. In Kharaka, Y., and Maest, S. (Eds.), Proc. 7 th Int. Symp. on Water-Rock Interaction: Rotterdam (Balkema), 1671-1674.

Takayanagi, M., and Ozima, M., 1987. Temporal variation of ${ }^{3} \mathrm{He} /{ }^{4} \mathrm{He}$ ratios recorded in deep-sea sediment cores. J. Geophys. Res., 92:12531-12538.

Taylor, S.R., and McLennan, S.M., 1985. The Continental Crust: Its Composition and Evolution: Oxford (Blackwell Scientific).

Trull, T., Perfit, M.R., and Kurz, M., 1990. He and Sr isotope constraints on subduction contributions to Woodlark Basin volcanism, Solomon Islands. Geochim. Cosmochim. Acta, 54:441-453.

Turner, G., and Stuart, F.M., 1992. He/heat ratios and the deposition temperatures of ocean-floor sulfides. Nature, 357:581-583.

Woodruff, L.G., and Shanks, W.C., 1988. Sulfur isotope study of chimney minerals and hydrothermal fluids from $21^{\circ} \mathrm{N}$, East Pacific Rise: hydrothermal sulfur sources and disequilibrium sulfate reduction. J. Geophys. Res., 93:4562-4572.

Zindler, A., and Hart, S.R., 1986. Helium: problematic primordial signals. Earth Planet. Sci. Lett., 79:1-8.

Date of initial receipt: 7 December 1992

Date of acceptance: 23 July 1993

Ms 139SR-227 